\title{
Samelewingsverandering en Skriftuurlike denkverandering
}

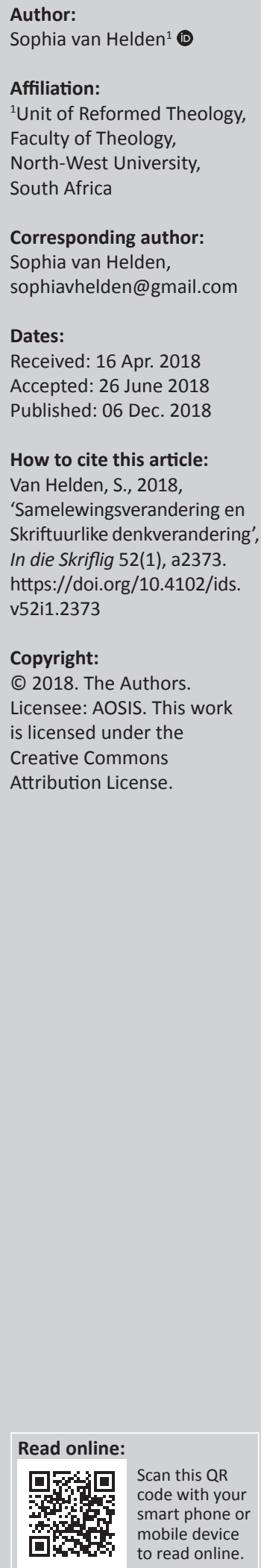

Change in society and scriptural thought changes. The declining traditional churches have undertaken to focus on scriptural thinking, striving for change in its calling of Missio-Dei. Missional thinking requires a paradigm shift which takes time. A change in thought at congregational level and specifically its members, is not occurring at the same pace. Thought change brings uncertainty - also at the level of church identity. The identity crisis within the traditional church, exacerbated by new groups within society, further hampers the churches' objective of missional change. The challenges posed by the pace of the changing context, are faster than traditional mainstream churches can accommodate. The diachronical approach regarding the declining mainstream churches and the influence of the fast developing society is directed according to different methodologies. This article seeks to raise the understanding regarding the identity crisis prevailing in the declining traditional churches, taking cognisance of the challenges that face such churches within an ever faster changing society.

\section{Inleiding}

Die tendens van krimping in die gereformeerde hoofstroomkerke het sedert die eeuwenteling al drie die susterkerk-gelowiges gedring tot besinning, denkverandering en omkeer tot gehoorsaamheid aan die Groot Opdrag. Al drie susterkerke het navorsing hieroor gedoen (o.a. Dreyer 2009a; Du Toit et al 2002; Van Helden 2010:333, 412) en die krisisafmetings jaar na jaar toenemend aan eie lyf begin voel. Die susterkerke het hulleself uitgespreek om deur daadwerklike besluite die tendens teë te werk en te probeer omkeer (Acta 2012:509-511; Dreyer 2009a; Niemandt 2007:65-70; Van Helden 2013b).

Denkverskuiwing binne die susterkerke moet egter nie net met die Groot Opdrag en gevolglike missionale bediening verbind word nie. Omdat lidmate van die hoofstroomkerke daagliks aan die huidige sekulêre samelewing blootgestel is, word die saak van denkverskuiwing onder ' $n$ vergrootglas geplaas (Alston \& Welker 2003:240, 250; Louw 2007). Denkverskuiwing vind dus eerstens, nie net terug na die missionale Woord toe plaas nie, dit vind tweedens, ook weg van die kerk af plaas.

Omdat denkverskuiwing 'n proses is wat met tyd ontwikkel, is dit nodig om denkverskuiwing in die krimpende gereformeerde kerke in die lig van gereformeerde identiteit in 'n postmodernistiese konteks diachronies na te vors en die resentste bevindings te formuleer. Denkverskuiwings oor die jare word dus gevolg en aan die groot klok gehang ter wille van bewusmaking van denktendense en ter versterking van die missionale bediening. Hierdie artikel is 'n prakties-teologiese studie wat deur die diachroniese benadering op die vorige navorsing uitbrei (Van Helden 2015b). Hierdie navorsing is deur literatuurstudie, asook deur kwalifiserende en kwantifisende navorsing gedoen.

\section{Is die krisissituasie werklik 'n krisis?}

Die krimpende getalle in die hoofstroomkerke het die volgende vraag die afgelope dekade na vore laat kom: Is die dalende tendens werklik 'n krisis? Soveel bronne maak gebruik van die woord krisis wanneer die tendens bespreek word (vgl. Van Helden 2013a) dat, by nabaat beskou, dit moontlik slegs 'n gonswoord geword het. Bronne wat nagegaan en artikels wat oor die krisis geskryf is, bevestig by herhaling die intensiteit van die toestand (vgl. Van Helden 2013a; 2013b; 2015a; 2016), asook die krimpende getalle wat jaarliks in die susterkerke se jaarboeke aangedui word. Daarby dui krimping in hoofstoomkerke op 'n uiters gekompliseerde verstrengeling van 'n groot verskeidenheid oorsake waarop hierdie artikel nie weer uitbrei nie (vgl. De Klerk \& Van Helden 2011). Ter verdieping van hierdie tendens is die mens se denke die dieptepunt agter die krisis (Van Helden 2013a). 
Denke is ten nouste verbind met identiteit (Lategan 2005:231-245). Indien daar nog dieper aan identiteit van gereformeerde kerkwees gekrap word, is die enkele besef waartoe gekom word dat skriftuurlike beginsels nie alleen die huidige identiteit van gereformeerde kerkwees bepaal nie (Dreyer 2015:1-5), maar wel die gereformeerde tradisie met voor- en afkeure; afkeure wat nie skriftuurlike beginsels is nie. Alston en Welker (2003:244) verwoord só 'n verskynsel soos volg: 'We seem to doubt whether it is indeed true that the revealed will of God should be obeyed ...'

Die identiteit van kerkwees volgens skriftuurlike beginsels het iewers ontspoor. Meer spesifiek, die gelowige denkraamwerk het ontspoor; gereformeerde gelowiges en leiers trap dubbele rye spore. Die gevolg is dat kerkwees nie ten volle skriftuurlike kerkwees is nie (Dreyer 2009a; Lategan 2005:231-245). Dit word onder andere duidelik wanneer leiers 'n dowe oor hou ten opsigte van die sendingopdrag (vgl. jaarboek-inskrywings onder die kolom toegevoeg deur evangelisasie). Kerkwees se taak is om die evangelie aan alle mense te verkondig en tog word dit nie as prioriteitopdrag gehoorsaam nie. Die kerk blom gevolglik in taakloosheid, doelloosheid en identiteitloosheid (Alston \& Welker 2003:244, 245; Dreyer 2009a). Die situasie is inderdaad 'n krisistoestand.

Sproul (2018) formuleer hierdie toestand soos volg: 'We don't know who God is and we don't know who we are.' 'n Kerk wat nie sy identiteit en roeping kan verwoord en kontekstueel leef nie, skort toewyding (Theron \& Van Tonder 2015:405-421), integriteit en geloofwaardigheid (Alston \& Welker 2003:250; Dreyer 2009a). Die kleinerwordende gemeentes - báie nog verknog aan eie voorkeurgewoontes in hul kerkwees - ervaar moeite om ' $n$ bereidheid vir skriftuurlike denkverandering te toon en volle skriftuurlike identiteit onder oë te neem. Die krisissituasie vertoon werklik die tekens wat Gilbert (2004:4-6) kort ná eeuwending al as 'slow death' verwoord het. Om die krisis met erns aan te pak, word skriftuurlike gereformeerde identiteit en verskuiwende denkparadigmas vervolgens onder die vergrootglas geplaas (vgl. Louw 2007).

\section{Gereformeerde identiteit en verskuiwende paradigmas}

Die Handwoordeboek van die Afrikaanse Taal (HAT Odendal \& Gouws 2010:437) stel dat identiteit op eenheid en voortbestaan van individualiteit dui. In gewone taal dui identiteit op 'n groep eendersdenkendes of ' $n$ individu wat weet wie hulle of hy is, waar hulle of hy hoort, bewus is van die taak of doel en dat dit sal kan bly voortbestaan. Individue in die kerk behoort dus elkeen te weet wie hy of sy binne kerkwees is, dat 'n wete en kennis van behoort ervaar word, versterk deur die wete dat dit volhoubaar is. Individue behoort daarom eenvormig te weet wat die wese van gereformeerde kerkwees is.

Om gereformeerde kerkwees-identiteit saam te vat, is volgens Smit en Hansen (2013:23) byna 'n onbegonne taak, aangesien die een wat só 'n samevatting waag uitspreek, óf oningelig, óf arrogant is oor wat die wydte, breedte en diepte van gereformeerdheid op elke moontlike plek ter wêreld inhou. Tog probeer Smit dit in 'n mate formuleer deur te sê dat gereformeerdheid ' $n$ manier van lewe (Coram Deo) in onderworpenheid aan die gesag van die Woord is (Niemandt 2007:74).

Só 'n formulering is egter só vaag dat dit op enige vorm van Christenskap kan dui. Die volgende vraag is dus: Wat is hierdie spesifieke manier van lewe, en dra die Woord werklik vir die mens van vandag nog gesag om op hierdie manier van lewe voort te gaan?

Dreyer (2015:1-5) stel dit onomwonde dat die krisis binne die kerk ontstaan omdat die manier van kerkwees, nie meer kerk is volgens die Skrif nie. Die eintlike vraag is dus: Wat behoort die kerk volgens die Skrif te doen om kerk te wees? Hierdie antwoord is kristalhelder en ongekompliseerd deur Jesus self gegee: Ek is met julle (indikatief), wat opgevolg word met die imperatief: Gaan maak dissipels (uitbou), doop en onderrig hulle (opbou) (Mat 28:18-20).

Die individue wat saamhoort, dink dus eenders oor die taak en essensie van die kerk, naamlik 'n eenheid van uitbou en opbou (Schalekamp 2005:23-28). Gelowiges wat nie tuis voel met hierdie eenheid nie, vertoon 'n mank identiteit. Dit bring weer die krisissituasie na vore. Dreyer (2015) skryf oor die identiteit en roeping van die kerk soos volg: 'If we do not accept that every biblical indicative is followed by an imperative, the church will remain in crisis and struggle with loss of credibility and integrity.'

Die teendeel van krimping, naamlik kerkgroei, se identiteitsgrond is dus in die Sender van die Groot Opdrag geleë (Bosch 1991:9), voortspruitend uit die Groot Gebod (Gilbert 2004:88-90; Van Helden 2010:446). Met dit direk uit die mond van Jesus self, is dit duidelik dat kerkwees van hierdie eeu binne die tradisionele gereformeerde kerke, nie is wat dit behoort te wees nie (vgl. Van Helden 2016). Omdat die kerk nie is wat sy bedoel is om te wees nie, voel lidmate dwalend en identiteitsoekend (Alston \& Welker 2003:250).

Hierdie dwalende, mank kerk word beleef en waargeneem deur ontnugterde kerklidmate (Alston \& Welker 2003:245), wat die afgelope paar dekades toenemend meer skepties oor kerkwees geraak het (Dreyer 2016). Die Afrikaanssprekende tradisionele gereformeerde kerke as instansie se verskuiwing na 'n sosiale randverskynsel, veral na 1994, manifesteer steeds toenemend. Om as randverskynsel boonop 'n mank identiteit bloot deur tradisionele gewoontes te probeer lewend hou, laat die ontnugterdes nóg meer ontnugter. Die identiteit van kerkwees, die veronderstelde Coram Dei-lewe, oortuig die hedendaagse mens net nie meer nie. Sinisme en privatisering van die eie godsdiens tree toenemend in (Alston \& Welker 2003:249). Sulke lidmate staan verleë (vgl. ook Gill 2003:5) en verdwyn liewers stilweg uit 'n gemeente, omdat hulle nie met kerkwees soos wat dit ervaar en waargeneem word, geïdentifiseer wil word nie (Alston \& Welker 2003:244, 245; Van Helden 2016). 


\section{Tradisionele identiteit gebou op die Woord en belydenisskrifte}

Die tradisionele gereformeerde identiteit toon tipiese kenmerke (Naude 2005:1-3). Die bekendste kenmerke is:

- Die Bybel staan sentraal as God se woord in mensetaal;

- Die kontekstuele verstaan van die Bybel word deur belydenisskrifte ondersteun (vgl. Smit \& Hansen 2013:8, 9);

- Kerklike gesag word Christologies en binne kerkverband verstaan;

- Die verbondsperspektief en wetsbeskouing dien as riglyn vir 'n dankbaarheidslewe;

- Geloofsekerheid dra groter klem as emosie;

- Liefde is die hoogste gawe;

- God se heerskappy strek oor die hele skepping en elke dimensie van die samelewing;

- God se koninkryk sal altyd onderdane hê;

- Geloof in die een, heilige, katolieke en Christelike kerk van alle eeue en alle plekke;

- Die solas en semper reformanda (staan voorop vgl. ook Smit \& Vorster 2000:515-534).

Die gereformeerde identiteit word veral na afloop van die 500-jarige reformasievieringe in 2017 opgesom aan die hand van vyf solas (Kuligin \& Yarbrough 2017; Lategan 2005:231-245). Deur die afgelope vyf eeue (1517-2018) was hierdie solas skriftuurlik die rigtinggewers vir gereformeerdes. Dit is die bondige belydenis van die tradisioneel gereformeerde stroom (vgl. Ef 2:20; Coetzee 2014; Lategan 2005:231-245).

Gereformeerddenkendes wat op die gevestigde tradisionele belydenisse staan, moet terselfdertyd deeglik bewus bly van die 500-jarige gelykmakende golfbeweging binne die Christendom. Dit behels dat 'n nuwe uitlewing ongeveer elke 500 jaar deur die Gees bewerkstellig word waardeur 'n nuwe Christelike praktyk na vore kom sodat die verspreiding van die Woord in die nuwe samelewingskonteks kan uitbrei (Tickle 2008:13-28, 123-150).

Na aanleiding van 'n bespreking oor die toepassing van die Protestantse solas binne die postmoderne konteks (Kinsey 2017:416-419), word die vraag gevra of die postmoderne sekulêre sondaarmens enigsins geraak word wanneer die tradisionele gereformeerde kerklidmaat hom of haar met hierdie evangelie-solas benader. Méér nog: Is die kerklidmaat enigsins in staat om die solas-belydenis as goeie boodskap aan die hedendaagse mens te bring? Is die opgesomde solasfeite enigsins relevant om die buitekerklike mens van die een-en-twintigste eeu tot bekering te lei (Louw 2007)?

Om dit te probeer antwoord, moet die volgende verstaan word: Die Heidelbergse Kategismus (Sondag 7, Vraag 21) stel dat geloof as kennis en vertroue geformuleer word. Kennis en vertroue word in 2018 soos volg verstaan: Kennis van die gereformeerde leer en waarhede staan onveranderbaar vas (Coetzee 2014:1-8; Lategan 2005:231-245), maar die mens van die een-en-twintigste eeuse konteks en ontvanklikheid of belewing (vertroue) in die kennis van hierdie ononderhandelbare leer in Jesus Christus, lê op 'n ander terrein.
Hierdie terrein is nog onontgin binne die gereformeerde tradisie (Coetzee 2014; Smit \& Vorster 2000; Stanley 2017:15-22). Dit kan moontlik as verduideliking aangevoer word waarom die buite-kerklike postmoderne mens nie deur gelowiges voor die lewende Christus gestel kan word nie.

Deur hierdie anderse stuwing in die samelewing, word die evangelisasieterrein nie net deur verstedeliking en globalisering tot op die voorstoep van die kerk gebring nie (Van Helden 2010:167), maar ook tot binne-in die kerk waar die skeptieswordende mens met sy of haar denke dalk nog in die kerk sit, of waar ook al hierdie mens aan Christendenke blootgestel word (Kinsey 2017:416-419). Van der Merwe et al (2013:1-12) noem dat die skeptiese mens 'n baie diep nood vertoon - 'n nood om sinvolheid te beleef, om as mens deel te wees tussen ander, om 'n bydrae te lewer, om deel van die groter volhoubare prentjie te wees en om God te dien deur ander op konstruktiewe wyse te betrek (Stanley 2017:15-22). Hierdie mens soek deur ervaring identiteit en kry dit nie in die kerk nie.

Dit gaan dus oor menslike ervaring en belewing wat dan tot vertroue behoort te lei. In die postmoderne konteks val die klem op subjektiwiteit, relatiwisme, logika en die wetenskap (Lategan 2005:231-245). Waarhede en strukture soos die gereformeerde belydenis, word nie verdra nie (Lategan 2005; Louw 2007; Theron \& Van Tonder 2015:405-421). Ongeag die onverdraagsaamheid teenoor gereformeerde waarhede, sal die waarheid van die Woord bly, maar tegelykertyd moet hierdie waarheid by die konteks van die nuwe eeu aansluiting vind. Die waarhede moet prakties in die huidige samelewingskonteks gedemonstreer, gekommunikeer en geleef word, sodat dit op geloofwaardige wyse ervaar of beleef kan word - met die doel om die postmoderne mens by vertroue en geloof uit te bring.

Vir tradisionele gereformeerdes is só 'n uitgangspunt moontlik te veel op die mens gefokus. Die waarheid is egter datdiehedendaagsemens dieeen is wat dieevangelieboodskap moet hoor. In talle gevalle is dit juis die mens wat ' $n$ dekade gelede nog sonder skeptisisme in die kerk gesit het. Dit is híerdie mens waarnatoe Matteus 28:18-20 die huidige gereformeerde gelowiges stuur. Hiérdie huidige postmoderne samelewing is juis die mens wat nie sy of haar ware sondenood binne die nuwe konteks besef nie (Sondag 1, Vraag 2a: gebrek aan kennis). Die fokus op die mens kan en mag nie geïgnoreer word nie. Die missionale opdrag wat die kerk het ter wille van die mens (vgl. Jackson 2018), mag nie geïgnoreer word nie. Verkondiging van redding gaan immers oor die verlore mens - dit is die taak en identiteit van gereformeerde kerkwees. Die kerk, predikante en opleidingsinstansies behoort die erns van die nuwe missionale aanpak te besef ter wille van hierdie mense in hulle sondedood (HK Sondag 2).

Dit is duidelik dat direkte bybelse kennis nie die aansluitingspunt by die hedendaagse mens kan wees nie. Daar moet by die vertroue-deel van geloof aansluiting gevind word - die vertroue-deel wat grootliks ' $n$ onbekende denkterrein 
en doenterrein vir die tradisioneel identiteitsoekende kerke is, maar óók onbekend is vir kerkwees wat wél skriftuurlike identiteit deur missionaalgerigte denke nastreef.

Deur die eeue was elke nuwe konteks se gelowige uitverkorenes as die kerk bekend (Coetzee 2014; Dreyer 2016). Die kerk was diegene wat waarlik gepoog het om te doen wat die Vader wil. Die missionale aspekte as die wil van God behoort in diepe erns deur die geestelike 'ingenieurs' (Niemandt 2007:34) opnuut eerlik ondersoek en kontekstueel onbevooroordeeld en onbeskaamd nuut geformuleer te word (Mark 8:38; Van Helden 2010:421-424). Reeds met die eeuwending is van die noodsaaklike heraanpassing en verskuiwing van denke melding gemaak (Smit \& Vorster 2000). Hierdie aanpassing wat nóú in die huidige postmoderne denkkonteks alreeds aksie vereis, is soms by uitsondering skrams deur 'n gemeente aangeraak (vgl. Van Helden 2016). Die oproep dat predikante en die kerk werk daarvan moet maak om die evangelie nuut te bring aan die postmoderne mens asook aan dié in armoede en in gestagneerde denke (Niemandt \& Meiring 2007; Smit \& Vorster 2000; Van Helden 2016), het grootliks agterweë gebly.

Die veranderende samelewing stel ontwikkelende groeperings bloot wat besig is om tradisionele gemeentes van binne-af so vinnig te erodeer dat die moontlikheid van die voorspelde inploffing (Dreyer 2009b) heel moontlik binne afsienbare tyd - dalk binne die volgende dekade - waargeneem behoort te kan word.

\section{Groeperings}

Sedert die diachroniese studie binne die Gereformeerde Kerke van Suid-Afrika (GKSA-steekproefgemeentes) in 2005 begin is, is die ontstaan van verskillende samelewingsgroeperings waargeneem:

- Daar is die gelowiges wat 'n omkeer en 'n denkskuif gemaak het, en die evangelie reformerend en missionaal wil uitbrei.

- Gelowiges maak egter nie hierdie denkskuif gelyktydig as 'n homogene groep nie. Denkverskuiwing vind dus nie teen dieselfde tempo plaas nie. Die wat stadiger by die Sender se opdrag aanpas, of bloot ter wille van kerklojaliteit of weens stagnasie en armoede steeds nog in die kerk is, is die groep wie se name saam met die vinniger reformerendmissionaaldenkendes op die boeke van die susterkerke is. Die jaarboeke van die Nederduitse Hervormde Kerk (NHK), Nederduitse Gereformeerde Kerk (NGK) en die Almanak van die GKSA dui dit jaarliks aan.

- 'n Onlangse studie is geloods om vas te stel waar die groot groep gereformeerde lidmate wat tog voorheen deel van die susterskerke was, dan heen is (Van Helden 2016). Groot getalle lidmate het stelselmatig en stil-stil verdwyn hetsy na ander denominasies;

- of om deel te word van die anderse soort godsdiensbelewing. Die anderse godsdiensbelewing is waar sodanige gelowiges hulleself steeds as Christene beskou, maar dan sónder 'n kerk;
- of die ander uiterste, naamlik om geloof heeltemal te verlaat (Van Helden 2016). Die steekproefgemeentes binne die GKSA vertoon die krimpende syfers van lidmate wat bloot verdwyn het - soos waargeneem gedurende die afgelope 12 jaar (2005-2018) (vgl. Van Helden 2018).

Opvallend is dat die groepering van hierdie anderse of verdwynende gelowiges, sedert die vorige navorsing (2016) 'n nuwe groepering na vore laat kom het, naamlik:

- die post-Christene (Stanley 2017:15-22). Omvou deur sekularisering, is hierdie groep se lewensbeskouing bloot om gelukkig te wees, om hulle gesonde verstand te gebruik en hiper-skepties te wees oor die wie en wat van die kerk.

\section{Post-Christene en nie-Christene}

Die verskil tussen post-Christene en nie-Christene is dat laasgenoemde groep niks van Christenskap weet nie en dus geen verwysingsraamwerk daarvan het nie. Post-Christene daarteenoor, ken alles en weet alles van Christenskap (vgl. vorige groepering wat uit die kerk wegbeweeg het). Hulle 'has been there, done that and has a closetful of camp T-shirts to show for it' (Stanley 2017:16).

Verdraagsaamheid van post-Christene teenoor enigiets van die kerk of die Skrif is uiters laag. Min tot geen geduld word getoon wanneer dit kom by geloofsantwoorde, feitegebaseerde vrae of 'n gesprek oor die Bybel of kerk nie. Vir hierdie groepering het logika, asook die ervaring van die tradisionele godsdiens (Bybel en identiteitlose kerkwees) nie tot eie geluk bygedra nie. Die Bybel dra vir hierdie groepering geen gesag nie. Post-Christene kom oral in die samelewing voor. Hulle kom soms tog wel nog in die kerk by familieaangeleenthede soos dope, troues en begrafnisse.

Post-Christene is uiters moeilik om te bereik, omdat hulle ' $n$ groot mate van kennis en ervaring van tradisionele kerkwees het, maar deur die ervaring daarvan en deur hulle logika, kerkwees of godsdiens nie geluk en beloning bewerk nie. Dit word nie meer as die moeite werd beskou nie. Godsdiens werk nie meer vir hierdie groep nie. Kerkwees word daarom met afkeer beskou en logiesgewys uit hulle lewe verwyder (Stanley 2017:17-19). Hierdie ontwikkeling binne die samelewingskonteks intensiveer die krisistendens.

\section{Kan daar 'n einde kom aan die krisis?}

Die krisis sal bly én toeneem indien die missio Dei-denke as identiteit van kerkwees nie verstaan en as grensverskuiwend en kruiskultureel-verskuiwend onder die knie gekry word nie (Walls 2002:29, 32). Die Opdrag behels dat gedoen moet word wat die Woord beveel. Om te gaan doen wat beveel is, beteken egter dat gelowiges oor sekere denkwyses moet besin en breek met dit waarmee die Woord nie ooreenstem nie. Daar moet dus diepgrondig gereformeer, omgekeer en aangepas word (Rm 12:2; Burger 2007:12; Dreyer 2015:1-5). Grense moet verskuif word. Semper reformanda behoort werklik aktiewe praktyk te wees. Dit wat die kerk skriftuurlik nie gewoond is om te bedink en te doen nie of wat nagelaat of 
gerieflikheidsonthalwe vergeet word, behoort in die toekoms bewustelik bedink en gedoen te word.

Die Skrif stel dat die mens dit wat hy wil behou, sal verloor, maar as die mens bereid is om alles te verloor ter wille van die koninkryk, hy dit sal behou wat verlore sou gaan (Mt 16:25). Binne die konteks van die Afrikaanssprekende, kan kultuur, taal en politiek as kerkweesbepalers steeds vir menige gelowige (vgl. Niemandt 2013a) in die pad van dissipelmaak staan. Groei in GKSA-gemeentes as gevolg van evangelisasie is grootliks afwesig (Van Helden 2010:333; 2016), terwyl evangelisasie en die maak van dissipels binne die GKSAkonteks van toegevoegde swart gemeentes gedurende die afgelope dekade, teëgestaan is deur armoede en die gestagneerde leefwyse (Van Helden 2016).

Met dit in gedagte, stel Oberholzer (Dreyer 2016) dat gereformeerde kerkwees baie doenig is met allerlei eksterne dinge - met alles behalwe om na God te luister, naamlik om skriftuurlik kerk te wees en die Woord nuut te bedink om dit binne die nuwe konteks steeds as tweesnydende swaard te kan gebruik. Die kerk wat skrifgebonde identiteit toon, sal die Woord só leer en só leef dat die mens van vandag (konteks) kan weet wat die werklike wese en taak (identiteit) van die kerk van Jesus Christus is. Die konstante, naamlik die Skrif bring die goeie boodskap vir die mens in enige en elke samelewingskonteks - in die verlede, in die hede en so ook in die toekoms (Bosch 1991:32).

Die konteks van die een-en-twintigste eeu behels tans die hede en die toekoms. Die nuwe-wyn-nuwe-sak-beginsel is hier ernstig ter sprake (Mt 9:17), naamlik om die konstante (Skrif as immer nuwe wyn) op só 'n wyse aan die veranderlike (nuwe konteks as nuwe sak) oor te dra sodat bekering van die huidige geslag kan plaasvind (vgl. ook Walls 1996:24, 25). Hierdie besef sowel as die oorgaan tot grensverskuiwende dade, ánders as om op die geykte tradisionele gereformeerde manier voort te gaan, vra geloofswaagmoed (Niemandt 2013b:157-165; Van der Merwe 2017).

Indien waagmoedige, skriftuurlike gehoorsaamheid nie 'n verskuiwende denkparadigma in die praktyk bewerkstellig nie, is dit duidelik dat krimpende gereformeerde kerke sal bly toeneem en dat die krisistendens sal aanhou. Dreyer (2015:1-5) stel die hardheid van hierdie tendens vanuit die kerk se perspektief, naamlik dat die 'huidige samelewing ondraaglik is vir die kerk'. Die kerk wys met só 'n gesindheid dat die samelewingskonteks nie met die taak van mank kerkwees korreleer nie. Dit wys die kerk se identiteitskrisis binne die huidige praktyk (konteks), want as kerkwees nie met die konteks te doen wil hê nie, is die kerk irrelevant en oorbodig.

Identiteit, kerkwees, konteks en kerkgroei hou op 'n intense vervlegte manier met mekaar verband (Coetzee 2014:1-8). Eerlik beskou is die konteks nie die eerste krisis in die kerk nie, maar wel gelowiges se identifisering met missionaalskriftuurlike kerkwees (kerkgroei). Die Skrif en die belydenisskrifte behoort wel en beslis onbevange herbestudeer te word, maar dan met die praktyk, die hedendaagse konteks, in gedagte (Coetzee 2014:1-8). Dit is die enigste roete om by dade uit te kom wat in hierdie nuwe, algeheelverskuiwende era die waarheid van die Woord aan die verlore mensdom kan bring. Louw (2007) stel baie duidelik dat die tyd aangebreek het dat ons onsself afvra of ons identiteit inderdaad opgesluit lê in dit wat ons sê dat ons glo, of kom identiteit na vore deur dade wat in die huidige toenemendonbekende konteks die volle skriftuurlike beginsels uitdra (kommunikeer).

\section{Krimpende hoofstroomkerke: Identiteitsoekend}

Met bogenoemde gestel, is dit duidelik dat die denkverskuiwingskrisis binne die susterkerke binne enkele jare ernstiger geword het (Dreyer 2003; 2015; Schoeman 2014; Van Helden 2016).

Veral sedert 2010 het bewuswording van 'n missionale paradigma na vore begin kom (Schoeman 2014). Lidmate en gemeentes sou dan deur hulle leiers méér missionaal gerig word om kerkwees volgens die Skrifvoorskrifte te leef: om die taak of identiteit van skriftuurlike kerkwees te leef sowel as te kommunikeer. Schoeman (2014) stel dat, ten spyte van hierdie bewuswording en voorneme, kerkwees in sy identiteit steeds grootliks as dwalend of identiteitsoekend beskryf kan word. Die werklikheid is dat ' $n$ missionale denkbenadering nog nie deur alle gereformeerdes as beginselriglyn gevolg word nie.

Die mening word verder gegee dat die hedendaagse postmoderne mens moontlik wél kerk toe sou wou kom indien die manier van kerkwees die ware identiteit van kerkwees sou wees - nie die ou tradisionele dwalende gewoontes, verbruikersfoefies of verdoeselde doelwitte as lokaas nie (Schoeman 2014; Van der Merwe et al. 2013:1-12). In die afgelope ongeveer twee dekades sedert die diachroniese studie geloods is, het die ontstaan van groeperings byna oornag ontwikkel wat duidelik spreek van die postmoderne denkverskuiwing rondom die verstaan van identiteit en kerkwees.

\section{Identiteit van kerkwees ter wille van onkerklikes}

Die kerk behoort bewus te wees van hierdie vinnig ontwikkelende groeperings en behoort voortdurend aan te pas om voorheen-Christene, maar nóú eerder onkerklikes, steeds in liefde te benader. Om hierdie groep te bereik, is moeiliker as om ongelowiges te bereik. Leiers in kerkwees behoort daarom krities bewus te wees dat 'n nuwe aanpak ter wille van die nuwe konteks bedink en gedoen moet word. Reeds met eeuwenteling (Smit \& Vorster 2000:515-534) is kommer uitgespreek dat leiers en gemeentes wat nie die missionale denkskuif neem nie, in denke nie vir die ontwikkelende kontekste gereed sal wees nie.

Die vraag ontstaan onwillekeurig: Watter roete kan gevolg word indien die tradisionele Bybelroete nie meer spreek en 
gebruik kan word nie? Ten spyte van die afwysing van die Bybel deur post-Christene, dui die Woord weereens - soos altyd - die koers en rigting aan. Matteus 10:16 en 9:17 saam met die Groot Opdrag bly die wegspringpunt. Kerkwees behoort na die mens van vandag toe te gaan. Die waarheid wat gebring word deur grensverskuiwende, waagmoedige daadChristene, behoort dan op ' $n$ manier gebring te word wat werklik spreek tot die huidige geslag - 'n geslag wat jou kinders en kleinkinders insluit (Stanley 2017:22).

Gereformeerde identiteit en kerkwees is dus om die gesindheid en bereidheid te hê om alle mense eerstens in liefde (1 Tm 2:1; Tit 2:11), met versigtigheid en waaksaamheid (Mt 10:11), en laastens aan die waarheid van die goeie nuus in Christus bloot te stel (Stanley 2017:22-32) - die waarheid wat in die lewende Jesus Christus is. Verkondiging van die tradisionele kerk en -struktuur maak nie deel uit van hierdie gaan nie (Smit \& Vorster 2000:515-534).

Die kinkel in die nuwe era is dat die Bybel nie meer vanselfsprekend gebruik kan word ter stawing van die goeie nuus nie, omdat die hedendaagse mens bottoe slaan bloot by die aanhoor van die woord Bybel. Dit bring die missionale gelowige by die uitdaging om 'n nuwe manier van aanpak te bedink; 'n nuwe manier wat huidig nog baie onbekend is en baie gebed en dinkwerk eis om dan beoefen te word met dade soos dié van Jesus Christus. Jesus Christus het reeds bestaan voordat die Bybel as kanon afgehandel is. Die bevrydende redding in Jesus was vóór kanonisering van die Bybel rééds die bron van goeie nuus. Dít, die belewing van die lewende Here, behoort as beginpunt aangegryp te word om die goeie nuus in die huidige konteks te bring. Christus is immers die Woord wat lewe wek en verskuiwend werk.

Uit die kerkwees wat Here Here sê (Mt 7:21-23), sal daar altyd diegene wees wat gehoorsaam die denke rig om deur geloof te lewe - geloof wat hoop daarstel (Burger 1995:75-85); geloof wat nie deur sinisme en menslike verleentheid ondergekry word nie. Die identiteit van kerkwees staan vas om in geloofshoop te leef (Kol 1:5), om hoopvol te getuig (1 Pt 3:15) en om waarlik gelowig en hoopvol missionaal kerk te wees - ook in die een-en-twintigste-eeuse konteks.

\section{Die taak van die kerk}

Die gaan, die bring van goeie nuus, asook om met bereidheid en gewilligheid teenoor buite- of onkerklikes in die samelewing te leef, is die kerk se taak (Mt 28:18-20). Leiers behoort bewus te wees van hierdie denkwerklikhede, dit missionaal te verwerk en irrelevante sake teë te werk. Bestaande gemeentelede wat in armoede en gestagneerde denke vasgevang is, behoort eerstens toegerus te word om missionaal te dink en te doen, en tweedens die evangelie gehoorsaam binne die veranderende samelewing te gaan uitdra. Die nuwewyn-nuwe-sak-beginsel is vandag met die krimpende kerke hiperaktueel (Mt 9:17; vgl. Walls 1996:24, 25).

Kerkwees in hierdie eeu en dekades word weereens daarvan bewus gemaak om die hedendaagse mens (konteks) die goeie nuus in Jesus Christus te laat ervaar. Die moeilikheidsgraad van hierdie taak verskil van gewone tradisionele evangelisasie, omdat die gewone tradisionele manier om die Bybel te gebruik hierdie groep mense afstoot. Die uiteinde van hierdie groepering is agnostisisme en nihilisme (Stanley 2017). Sulke voorheen-Christene is presies dié mense wat nog nie verlos is nie en na wie die kerkmens - op Christus se bevel - behoort uit te reik. Die kerkgelowige se denke en liefde vir verloregaande mense word deur die een-en-twintigste-eeuse konteks ernstig onder die soeklig geplaas. Gemeentelike denke en liefde vir verloregaande mense behoort gerig en aangevuur te word deur die leiers. Aangesien krimpende gemeentes die tendens bly weens onder andere die postmoderne mens se besluit om nie met die tradisionele identiteit van kerkwees te identifiseer nie, is geestelike leiers en teologiese toerusting en opleiding ook ernstig in die spervuur (Dreyer 2015:1-5; Marais 2017; Van Helden 2010:279). Die samelewingskonteks, in die breedste sin van die woord, het die afgelope 15 jaar van navorsing só drasties verander dat gelowiges, predikante en opleidingsinstansies deeglik hiervan behoort kennis te neem.

Die taak van die kerk sluit egter ook gelowe in wat toenemend al meer prominent raak in die samelewing, byvoorbeeld die Islam (Visser 2012:78-88). Dringende planne behoort bedink te word om meer arbeiders op 'n baie vinniger en gesagvolle manier toe te laat tot evangelieverkondiging binne die omgewing waar gewoon word (vgl. Dreyer 2015; Stanley 2017:19).

Soos die sendingopdrag en die omkeeroproep die tradisionele kerk en kerkleiers op 'n onbekende terrein geplaas het, net so onbekend is hierdie samelewingsterrein vir die lewende kerklidmate. $\mathrm{Na}$ aanleiding van die 2018-navorsing onder die GKSA-steekproefgemeentes behoort leiers hierdie tradisionele krimpende gemeentes asook die onlangs toegevoegde gestagneerde niegroeiende GKSA-gemeentes, doelbewus te lei en toe te rus om missionale grensverskuiwende denke te ontwikkel ter wille van die huidige samelewing (Van Helden 2016).

\section{Steeds krimpende getalle: 2018 diachroniese navorsing in GKSA- steekproefgemeentes}

'n Diachroniese studie word sedert 2005 gedoen om die krimpende tendens in die tradisonele gereformeerde kerkverbande, met die fokus op GKSA-steekproefgemeentes, te monitor. In die gereformeerde tradisie is reeds kennis geneem van die skriftuurlike beginsels om gesonde groei moontlik te maak (vgl. Van Helden 2010). Aanvaarding van gesonde groeibeginsels en ' $\mathrm{n}$ omkeer- of bekeringsproses om groei moontlik te maak, is gelyklopend. Die feit dat leiers en gemeentes nie ' $n$ eenvormige bekeringspoging beleef nie (Brouwer et al. 2007:49), is ook waargeneem in die GKSA-steekproefgemeentes. Slegs enkele gemeentes het tot 'n sigbare omkeerpoging oorgegaan om daadwerklik gesonde omstandighede daar te probeer stel (Van Helden 2015a; 2016). 
Aangesien dit die realiteit is dat omkeer teen verskillende tempo's plaasvind en die samelewing terselfdertyd teen 'n vinniger tempo ontwikkel en bykomende denkaanpassings van kerkwees eis, bly dit 'n nodige prakties-teologiese navorsingsonderwerp. Hierdie studie gee 'n samevatting van die krimpende tendens soos aan die hand van die GKSAAlmanakke sedert 2005 gemonitor is, asook 'n opsomming vanaf 2012 toe die GKSA 'n sinodebesluit geneem het om as kerkverband op kerkgroei te fokus (omkeerstrategie). Die statistiek vir die GKSA-steekproefgemeentes is, soos vir vorige navorsing, deur middel van die 2018-Almanak bekom (Bain et al 2018).

Ook die mees onlangse statistiek binne die GKSA bevestig die voortgaande krimpende tendens (sien Boks 1).

Die 2005-2018-navorsing, aan die hand van die GKSAsteekproefgemeentes, word vervolgens kortliks genoem. Vanaf 2005 is steekproefgemeentes volgens Groot (G), Tussen-in (T) en Klein (K) gemeentes (vgl. Van Helden 2015a) binne elke klassis vasgestel. Gemeentes wat vakant of saamgesmelt het, word as krimpende gemeentes beskou en word nie by groeiende gemeentes genoem nie.

Die vorige navorsing wat in 2015 en 2016 gepubliseer is na aanleiding van dieselfde steekproefgemeentes oor krimpende en groeiende gemeentes (Van Helden 2016), het getoon dat al die steekproefgemeentes in die 26 klassisse krimping ervaar, behalwe vir nege gemeentes. Hierdie jaar (2018) word die navorsing opgevolg om groei vanaf 2008 tot 2018 in dieselfde steekproefgemeentes na te gaan (Bain et al 2018; Van Helden 2015b) (sien Figuur 1).

Uit die genoemde nege gemeentes wat tot 2015 'n mate van groei in getalle getoon het, het daar sedert die vorige navorsing krimping by twee van die gemeentes begin intree, terwyl groei steeds in die ander sewe gemeentes plaasgevind het (Van Helden 2016). 'n Enkele steekproefgemeente, naamlik Jeffreysbaai, het tot en met die 2015-navorsing nie groei getoon nie. Die afgelope drie jaar het daar wel ' $n$ mate van getalletoename in dié een gemeente plaasgevind (sien Boks 2).

Die redes vir groei (Van Helden 2016) is steeds van toepassing op die sewe groeiende gemeentes. Die hoofredes vir groei in Jeffreysbaai as die een gemeente wat by die groeiende steekproefgemeentes toegevoeg is, is volgens ds. Jobse (2018), die volgende:

- Effektiewe balans binne die eenheidsisteem van uitbou en opbou: suiwer, aktuele en verstaanbare Woordbediening, beter funksionering van die dienste van ouderling en diaken, gereelde huisbesoek deur die predikant, ouderlinge en diakens, toename in gasvryheid, hartlikheid

BOKS 1: 2017 tot 2018.

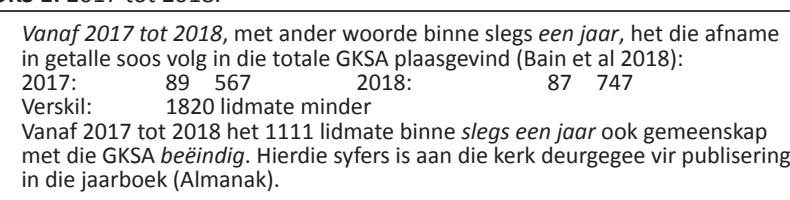
in die jaarboek (Almanak).

en warmte in die gemeente veral teenoor besoekers, lidmate wat nie skaam is om daagliks van Christus te getuig nie, gemeentebou-aksies, evangelisasie en uitreike (in groepe, maar ook individueel), 'n gefokusde jeugbediening, Bybelstudie-geleenthede wat amper soos kleingroepe funksioneer, aansluit van lidmate uit NG Kerk, doelgerigte doelwitstelling.

- As kusdorp is Jeffreysbaai 'n gewilde aftreeplek.

In die swart toegevoegde gemeente waar groei tot en met 2015 beleef is, lyk die statistiek in die steekproefgemeente tans (2018) soos uiteengesit in Boks 3 (Van Helden 2016).

Wapadrand (G)

$\begin{array}{ccc}\text { Jaar } & \boldsymbol{n} & \\ 2008 & 1495 & \\ 2018 & 1724 & \text { Toon steeds groei }\end{array}$

Kathu (T)

$\begin{array}{lll}2008 & 178 & \\ 2018 & 219 & \text { Toon steeds groei }\end{array}$

Olifantshoek (K)

$\begin{array}{lll}2008 & 82 & \\ 2018 & 87 & \text { Toon steeds groei }\end{array}$

Port Elizabeth (G)

$\begin{array}{lll}2008 & 397 & \\ 2018 & 410 & \text { Toon steeds groei }\end{array}$

Belville (G)

$\begin{array}{lll}2008 & 437 & \\ 2018 & 406 & \text { Toon Krimping }\end{array}$

Stellenbosch $(T)$

$\begin{array}{lll}2008 & 224 & \\ 2018 & 295 & \text { Toon steeds groei }\end{array}$

Heilbron (T)

$\begin{array}{lll}2008 & 128 & \\ 2018 & 135 & \text { Toon steeds groei }\end{array}$

Mariental (K)

$\begin{array}{lll}2008 & 53 & \\ 2018 & 62 & \text { Toon steeds groei }\end{array}$

Grassypark (K)

$\begin{array}{lll}2008 & 113 & \\ 2018 & 108 & \text { Toon Krimping }\end{array}$

Bron: Van Helden, S., 2016, 'Waar is die gereformeerde lidmate dan?', In die Skriflig/In Luce Verbi 50(1), a2073. https://doi.org/10.4102/ids.v50i1.2073

FIGUUR 1: Steekproefgemeentes - Groei en krimping 2008-2018.

BOKS 2: Steekproefgemeente - 2005-2018.

\begin{tabular}{lccccccc}
\hline Jeffreysbaai $(T)$ & & & & & & & \\
& 2005 & 2006 & 2007 & 2008 & 2015 & 2017 & 2018 \\
& 216 & 230 & 228 & 227 & 214 & 222 & 236
\end{tabular}

Bronne: Van Helden 2015a; 2015b; 2016; Bain et al 2018 
BOKS 3: Reformed Family Worship Church (RFWC) - Ds. S. Phungula (2015-2018).

\begin{tabular}{|lll|}
\hline 2015 & 192 & \\
2017 & 183 & \\
2018 & 175 & Toon krimping \\
\hline
\end{tabular}

Bron: Van Helden, S., 2016, 'Waar is die gereformeerde lidmate dan?', In die Skriflig/In Luce Verbi 50(1), a2073. https://doi.org/10.4102/ids.v50i1.2073

In 'n e-pos wat van ds. Phungula op 2 Februarie 2018 ontvang is, is die enkele rede vir krimping die enorme tekort aan predikante. Die RFWC bestaan uit nege wyke wat wydverspreid oor die westelike deel van Durban is (Clermont aan die noordelike deel van Pinetown, Ndengezi, wes van Pinetown, asookHammarsdale). Verder sluit RFWCookPietermaritzburg in en vyf wyke rondom Richmond. Om hierdie wyke volhoubaar te laat groei, word predikante in elke wyk benodig. Die oes is groot, maar die arbeiders min (Mt 9:35-38). As gevolg van bedieningstekorte is ongeveer 15 lidmate aan 'n ander denominasie afgestaan.

\section{Diepsloot: Wyk van Randburg - Ds. K. Semenya}

Hierdie wyk is deel van die Gereformeerde Kerk Randburg. Die wyk is nie ' $n$ selfstandige gemeente nie. In die vorige navorsing is melding gemaak van groei in hierdie wyk en bevindings is in In die Skriflig gepubliseer (Van Helden 2016). In 'n opvolg oor die stand van hierdie wyk na drie jaar, het ds. Kwena Semenya in 'n e-pos op 26 Januarie 2018 die volgende genoem:

Die kerk in Diepsloot het tot 2016 vinnige groei beleef. Teen die einde van 2016 en deur die loop van 2017 het wyksgetalle dramaties afgeneem. Die gebeure het die 2015-lidmaattal van 500 lidmate laat afneem tot 320 teen die einde van 2016. In die verloop van 2017 het groei weer begin plaasvind. Die wyk staan tans op 410 lidmate.

Die rede hiervoor was onderlinge struwelinge, jaloesie, ontevredenheid, onredelike gedrag en twis wat deur vyf ou dames en hulle families teenoor die predikant gevoer is. Die grootste enkele probleem in die wyk is die afhanklikheidsindroom. Dit beteken dat wykslede nie hulle eie verantwoordelikhede in die wyk wil aanvaar nie en dit op die Randburg-gemeente afskuif. Die Randburg-gemeente het pogings aangewend om die saak te beredder, maar sonder sukses. Intussen het die onrusstokers die kerk verlaat.

\section{Samevattende gevolgtrekking}

Die 2018-navorsing onder krimpende en groeiende GKSAsteekproefgemeentes toon dat drie van die nege voorheen groeiende steekproefgemeentes na drie jaar'n afname in getalle toon (Belville, Grassy Park en Reformed Family Worship Church). Een steekproefgemeente wat voorheen nie groei ervaar het nie (Jeffreysbaai), toon groei. Ook die Randburgwyk wat tydelik 'n terugval beleef het, het weer begin groei. Die poging om gesonde groei moontlik te maak, is die strewe by laasgenoemde twee gemeentes. Intergemeentelike verskuiwings van gemeentelede wat getalle in gemeentes kan laat toeneem, word nie as groei weens 'n missionale bediening gereken nie.

\section{Gevolgtrekking}

Die enkele gemeentes wat die denkskuif gemaak het soos voorgeneem is met die omkeerbesluit ter wille van 'n missionale bediening, is meer bewus van die veranderende samelewing as dié gemeentes wat nog nie daartoe oorgegaan het nie. Die samelewing verander so vinnig dat binne die bestek van enkele jare nuwe samelewingsgroeperings ontwikkel. Die groeperings verbreed die sendingveld rondom die bestaande tradisionele gemeentes teen 'n pas wat vinniger is as wat gemeentes van voorneme is om missionaal te dink en te doen. Die realiteit van postmoderne denkwyses, asook die nihilistiese en ander godsdienstige denke is vinniger voor die deur van die kerk as wat die tradisionele kerkmens se denke aanpas. Die samelewingsveranderings maak plek vir 'n nuwe, onbekende leefwêreld (vgl. Niemand 2013b:65-69), waarbinne die evangelie op 'n geheel nuwe manier gebring moet word-'n konteks wat die denkkrisis in die gereformeerde hoofstroomkerke verdiep.

Die uitbreidende sendingveld direk om gemeentes het nodig om die verlossing in Christus te hoor. Die meerderheid tradisionele gemeentes het egter nog nie by missionale denke uitgekom nie. Hierdie eerste denkskuif ter wille van missionale denke, skriftuurlike kerkwees en identiteit, is nog nie gemaak nie. Die omkeer ter wille van gehoorsaamheid aan die Groot Gebod en Groot Opdrag is deur talle gemeentes steeds nog nie behoorlik deurdink of verwerk nie. Die manier van kerkwees en gereformeerde identiteit is daarom nog nie ten volle volgens die Skrif nie. Evangelisasie en sending is vir tradisionele gemeentes in die huidige dekade steeds ' $n$ vae, veraf terrein. Denkaanpassings ter wille van verloregaande mense in die vinnig veranderende konteks is in baie gemeentes glad nie ter sprake nie.

Diegene wat wel in die proses is om die missionale denkskuif te maak, staan dus reeds weer voor 'n volgende denkuitdaging, naamlik hoe om die Bybel-afwysende, postmoderne, buitekerklike mens te benader. Hierdie onbekende sendingterrein, die geleidelike inploffing van gemeentes, die mank identiteit en die vinnige samelewingsveranderings, is faktore wat tradisionele gemeentes direk raak. Die konteksveranderings van hierdie eeu, waaronder ook die krimpende kerke, is in hierdie eerste twee dekades insiggewend, veral wanneer in gedagte gehou word dat die 500-jarige gelykmakende golfbeweging (1517 tot 2018) volgens verwagting nuwe kontekste daar sal stel en bestaande kontekste sal wysig en verwyder ter wille van die uitbreiding van die evangelie. Die krimpende gereformeerde stroom - lidmate, leiers, predikante en opleidingsinstansies behoort te besef dat vinniger, meer diepgaande en waagmoediger denkaanpassings gemaak behoort te word om die skriftuurlike waarhede kontekstueel uit te dra.

\section{Erkenning Mededingende belange}

Die outeur verklaar dat sy geen finansiële of persoonlike verbintenis het met enige party wat haar nadelig of voordelig kon beïnvloed het in die skryf van hierdie artikel nie. 


\section{Literatuurverwysings}

Acta, 2012, kyk Gereformeerde Kerke in Suid-Afrika.

Alston, W.M. Jr. \& Welker, M. (eds.), 2003, Reformed theology identity and ecumenicity, William B Eerdmans Publishing Company, Grand Rapids, MI.

Bain, R., Coetzee, P.A., Masase, P.T., Mathundela, C.C., Erasmus, M.C., Fourie, J. et al., 2018, Die Almanak van die Gereformeerde Kerke in Suid-Arika vir die jaar 2018 Jaargang 144, V\&R Drukkery, Pretoria.

Bosch, D.J., 1991, Transforming mission shifts in theology of mission, Orbis Books, New York.

Brouwer, R., De Groot, K., De Roest, H., Sengers, E. \& Stoppels, S. (eds.), 2007, Levend liggaam: Dynamiek van christelijke geloofsgemeenschappen in Nederland, Kok Kampen.

Burger, C., 1995, Gemeentes in transito - vernuwingsgeleenthede in 'n oorgangstyd, Lux Verbi, Kaapstad.

Burger, I., 2007, 'Kerk groei al hoe meer in Europa', Beeld, 17 September, p. 12.

Coetzee, F.C., 2014, 'Die plek en funksie van die Heidelbergse Kategismus in ' $n$ omkeerstrategie in die Gereformeerde Kerke in Suid-Afrika', In die Skriflig 48, 1-8. https://doi.org/10.4102/ids.v48i1.1785

De Klerk, B.H. \& Van Helden, P., 2011, 'Oorsake van kerkkrimping binne die tradisionee Afrikaanssprekende gereformeerde kerke in Suid-Afrika', Verbum et Ecclesia 32(1), Art.\#477, 10 p. https://doi.org/10.4102/ve.v32i1.477

Dreyer, T.F.J., 2003, 'Statistieke vertel 'n storie: 'n Visie vir die Hervormde Kerk op pad na 2010, HTS Teologiese Studies/Theological Studies 59(4), 1045-1062. https:// doi.org/10.4102/hts.v59i4.685

Dreyer, W., 2009a, "n Prakties-teologiese perspektief op kerkwees met besondere verwysing na die Nederduitsch Hervormde Kerk van Afrika', PhD-proefskrif, Fakulteit Praktiese Teologie, Universiteit van Pretoria, Pretoria.

Dreyer, W., 2009b, Die kleiner kerk en gemeente, besigtig 12 Januarie 2015, vanaf http://www.google.co.za/url?sa=t\&rct=j\&q=\&esrc=s\&source=web\&cd=16\&ved OCDgQFjAFOAo\&url=http $\% 3 \mathrm{~A} \% 2 \mathrm{~F} \% 2 \mathrm{Fwww}$.gemeentes.co.za $\% 2$ Fdokumente $\% 2$ Fkruisgewys \%2Fklein_gemeentes\%2FNHKA\%2520Klein\%2520Kerk.doc\&ei= Ib2wVPehDMf-Us_agMAK\&usg=AFQjCNEe1Zs21c4dAEmjeZy5k5bD_687CQ\&sig2= mQ366Dsu1puoei9M8IKWvQ

Dreyer, W., 2015, 'The real crisis of the church', Theological Studies 71, 1-5. https:// doi.org/10.4102/hts.v71i3.2822

Du Toit, F., Hofmeyr, H., Strauss, P. \& Van der Merwe, J., 2002, Moeisame pad na vernuwing: Die NG Kerk se pad van isolasie en die soeke na 'n nuwe relevansie, Barnabas, Bloemfontein.

Gereformeerde Kerke in Suid-Afrika, 2012, Acta - Handelinge van die tweede algemene sinode te Potchefstroom op 4 Januarie 2012 en volgende dae, V\&R Drukkery, Pretoria.

Gilbert, D.E., 2004, “"Deep change" or "slow death"? A practical road guide for the highway of change: A learning manual for church boards submitted for the Western Theological Seminary in partial fulfillment of the requirements of the degree of Doctor of Ministry' [TREN DATABASIS (Theologica Research Exchange Network) TREN.com receipt 2009021113263711 Februarie 2009]

Gill, R., 2003, The 'empty' church revisited, Burlington, Ashgate.

Jackson, N., 2018, 'n Ou roeping in 'n nuwe omgewing, Die Kerk-e-bode, 22 Januarie, besigtig 26 Januarie 2018, vanaf http://kerkbode.christians.co.za/2018/01/22/nou-roeping-n-nuwe-omgewing/

Jobse, W., 2018, e-pos, 15 Januarie 2018, wilhanjobse@gmail.com

Kinsey, A.D., 2017, 'Biblical authority after Babel: Retrieving the protestant solas in the spirit of mere Protestant Christianity', by Vanhoozer, K.J., 2016, Christian Scholar's Review 46(4), 416-419.

Kuligin, V. \& Yarbrough, R., 2017, In Christus alleen, CUM, Vereeniging.

Lategan, L.O.K., 2005, 'Die plek en roeping van die Nederduitse Gereformeerde Kerk in 'n postmoderne wêreld: riglyne vir kerklike hernuwing', Tydskrif vir Christelike Wetenskap 41, 231-245.

Louw, L., 2007, Die grense van gereformeerde teologie, Die Kerkbode 179(5), 7, September 28, Lente.

Marais, F., 2017, 'Teologiese opleiding vir missionale bediening', Die Kerk-e-bode 15 besigtig 15 Januarie 2018, vanaf http://kerkbode.christians.co.za/2017/12/15/ teologiese-opleiding-vir-missionale-bediening/
Naude, P., 2005, 'Gereformeerde identiteit in tien stellings', Die Kerkbode 174(9), 1-3. Niemandt, N., 2007, Nuwe drome vir nuwe werklikhede, Lux VerbiBM, Wellington.

Niemandt, N., 2013a, Krimpende lidmaatgetalle, besigtig 08 Januarie 2015, vanaf https://www.facebook.com/nelus.niemandt/posts/10151206315221975

Niemandt, N., 2013b, Nuwe leiers vir nuwe werklikhede, Christelike Uitgewersmaatskappy, Vereeniging.

Niemandt, N. \& Meiring, P., 2007, Raamwerkdokument oor die missionale aard en roeping van die NG Kerk, besigtig 12 Januarie 2018, vanaf http://www.google. co.za/search?q=Die+grense+van+gereformeerde+teologie+gereformeerde+ident iteit\&ei=LdeBWsC_NIH1gAbCko-oCg\&start=208sa=N\&biw=1034\&bih=61

Odendal, F.F. \& Gouws, R.H., 2010, Handwoordeboek van die Afrikaanse Taal, 5e uitgawe, Pearson Education South Africa, Pinelands.

Phungula, S., 2018, e-pos, 2 Februarie, phungulasz@gmail.com

Schalekamp, M.E., 2005, 'Missiones Ecclesiae: 'n Missionêre visie en strategie in gemeentebou ten opsigte van multikulturele kerkplanting', PhD-proefskrif, Fakulteit Teologie, Noordwes-Universiteit, Potchefstroom.

Schoeman, W.J., 2014, 'Agter die syfers is gelowiges, gemeentes en die kerk, 'n prakties teologiese refleksie oor lidmaatskap', Theological Studies 70, 1-10. https://doi.org/10.4102/hts.v70i1.2677

Semenya, K., 2018, e-pos, 26 Januarie, kwena@gkrandburg.org.za

Smit, C.J. \& Vorster, J.M., 2000, 'Die GKSA en sy gereformeerde identiteit: Kan dit behou word in 'n postmoderne gemeenskap?', In die Skriflig 34(4), 515-534.

Smit, D.J. \& Hansen, L.D. (reds.), 2013, Opstelle oor Gereformeerde-wees vandag: Versamelde opstelle 4, Sun Press, Stellenbosch.

Sproul, R.C., 2018, Sproul rebukes the modern church, viewed 26 January 2018, from https://www.youtube.com/watch?v=gFSndhk1q5Q

Stanley, A., 2017, Going deep \& wide, Zondervan Harper Collins Publishers, Grand Rapids, MI.

Theron, E. \& Van Tonder, S., 2015, 'Kerktoewyding deur die jonger generasies : Hou verhoudingsbemarking die sleutel?: Navorsings- en oorsigartikels', Tydskrif vir Geesteswetenskappe 55, 405-421. https://doi.org/10.17159/2224-7912/2015/ v55n3a6

Tickle, P., 2008, The great emergence, Baker Books, Grand Rapids, MI.

Van der Merwe, J., 2017, 'Om gereformeerd te wees vra waagmoed', Die Kerkbode, 19 Oktober, besigtig 12 Januarie 2018, vanaf http://kerkbode.christians.co. za/2017/10/19/om-gereformeerd-te-wees-vra-waagmoed/

Van der Merwe, M.C., Grobler, A., Strasheim, A. \& Orton, L., 2013, 'Getting young adults back to church, a marketing approach', Theological Studies 69, 1-12.

Van Helden, P., 2013a, 'Denke as krisisterrein in die verskynsel van kerkkrimping by tradisioneel Afrikaanssprekende susterkerke', Verbum et Ecclesia 34(1). Art. \#677, 12 pages. https://doi.org/10.4102/hts.v69i2.1326

Van Helden, S., 2010, “'n Hermeneuties-empiriese strategie rakende die verskynsel van kerkkrimping in tradisioneel Afrikaanse susterkerke in Suid Afrika": 'n Prakties-teologiese studie', PhD-proefskrif, Fakulteit Teologie, NWU, Potchefstroom.

Van Helden, S., 2013b, 'Verskuiwende denke van die 2012-GKSA-Sinode', In die Skriflig/In Luce Verbi 47(1), Art. \#117, 16 pages.

Van Helden, S., 2015a, 'Ontluikende denke in die GKSA-kerkgroeibediening', In die Skriflig/In Luce Verbi 49(1), Art. \#1978, 12 pages.

Van Helden, S., 2015b, Data van belydende lidmaatgetalle in klassisse met Groot (G), Tussen-in (T) en Klein (K)-gemeentes, Databasis, Kerkgroei Deputate.

Van Helden, S., 2016, 'Waar is die gereformeerde lidmate dan?', In die Skriflig/In Luce Verbi 50(1), a2073. https://doi.org/10.4102/ids.v50i1.2073

Van Helden, S., 2018, Data van lidmaatgetalle in klassisse met Groot (G), Tussen-in (T) en Klein (K)-gemeentes, Databasis, Kerkgroei Deputate.

Visser, F., 2012, 'Living out Reformed theology and identity in relation to the nonChristian "other"', Reformed World 62(2), 78-88.

Walls, A.F., 1996, The missionary movement in Christian history - studies in the transmission of faith, T\&T Clark, Edinburgh.

Walls, A.F., 2002, The Cross-cultural process in Christian history - Studies in the Transmission and Appropriation of Faith, T\&T Clark, Edinburgh. 